\title{
ANALISIS AUDIT KEPATUHAN TERHADAP PROSEDUR PEMBERIAN PEMBIAYAAN MODAL KERJA PADA BANK SULSELBAR CABANG SYARIAH MAKASSAR
}

\author{
Abdul Khaliq \\ Universitas Muhammadiyah Makassar \\ Email: abdulkhaliq@unismuh.ac.id
}

\begin{abstract}
This study aims to analyze compliance audit of the working capital financing procedure at Bank Sulselbar Makassar Sharia Branch. The method of analysis used in this research is qualitative analysis method. In this case, the researcher uses a risk-based audit approach, an audit approach which checks the harmony between the policies and the procedures performed by the regulations. Thus, Bank Sulselbar Makassar Sharia Branch must be in line with regulations or procedures that have been held by Bank Indo nesia (BI) in terms of financing. Based on the result of the research, it shows that the Compliance Audit conducted by Compliance Director and Compliance Unit of Bank Sulselbar Makassar Sharia Branch has been running well in accordance with its duties and authority and maintaining its independence well because it has work guidance, work system and procedures that have been referring to the provisions current regulation. Likewise in terms of providing working capital financing to customers has been in accordance with applicable procedures. All financing stages or procedures have been implemented or followed before financing decision can be realized. And each stage is not immune from the supervision of the Compliance Group so that any part or section concerned at that stage is professionally responsible.
\end{abstract}

Keywords: Compliance Audit, Working Capital Financing Procedure

\begin{abstract}
Abstrak
Penelitian ini bertujuan untuk menganalisis audit kepatuhan terhadap prosedur pemberian pembiayaan modal kerja pada Bank Sulselbar Cabang Syariah Makassar. Metode analisis yang digunakan dalam penelitian ini adalah metode analisis kualitatif. Dalam hal ini peneliti menggunakan pendekatan audit berbasis risiko, yaitu pendekatan audit dimana dilakukan pengecekan terhadap keselarasan antara kebijakan dan prosedur yang dilakukan dengan ketetapan regulasi. Jadi, Bank Sulselbar Cabang Syariah Makassar harus sejalan dengan peraturan atau prosedur yang telah diadakan oleh Bank Indonesia (BI) dalam hal pembiayaan.Berdasarkan hasil penelitian, menunjukkan bahwa Audit Kepatuhan yang dilaksanakan oleh Direktur Kepatuhan dan Satuan Kerja Kepatuhan Bank Sulselbar Cabang Syariah Makassar telah berjalan dengan baik sesuai dengan tugas dan kewenangannya dan menjaga independensinya dengan baik karena memiliki pedoman kerja, sistem dan prosedur kerja yang telah mengacu kepada ketentuan perundang-undangan yang berlaku. Begitupun dalam hal pemberian pembiayaan modal kerja kepada nasabah telah sesuai dengan prosedur yang berlaku. Seluruh tahapan-tahapan atau prosedur pembiayaan telah dilaksanakan atau dipatuhi sebelum pengambilan keputusan pembiayaan dapat direalisasikan. Dan setiap tahapan tersebut tidak luput dari pengawasan Grup Kepatuhan agar setiap bagian atau seksi yang terkait pada tahapan tersebut bertanggung jawab secara profesional.
\end{abstract}

Kata Kunci : Audit Kepatuhan, Prosedur Pemberian Pembiayaan Modal Kerja 


\section{PENDAHULUAN}

Peran perbankan di saat seperti ini sangatlah penting bagi kemajuan ekonomi, tidak terkecuali perbankan syariah yang saat ini pertumbuhannya sudah berkembang di Indonesia. Dengan semakin berkembangnya kegiatan ekonomi tersebut, semakin banyak pula yang ingin mengembangkan usaha-usaha yang mereka lakuk an. Oleh karena itu diperlukan adanya sumber-sumber yang membiayai kegiatan usaha mereka.

Salah satunya adalah pembiayaan dalam perbankan syariah dengan menggunakan sistem bagi hasil. Dengan menggunakan sistem bagi hasil nasabah tidak perlu memikirkan berapa besar bunga yang harus dibayarkan setiap bulannya. Dengan adanya pembiayaan sangatlah penting bagi faktor pembangunan ekonomi, hal ini sangat berpengaruh dalam berbagai aspek seperti perdagangan, perindustrian, perumahan dan bahkan transportasi.

Menurut Kasmir (2011), pembiayaan adalah penyediaan uang atau tagihan yang dapat dipersamakan dengan itu, berdasarkan pada persetujuan atau kesepakatan antara bank dengan pihak lain yang mewajibkan pihak yang dibiayai untuk mengembalikan uang atau tagihan tersebut setelah jangka waktu tertentu dengan imbalan atau bagi hasil.

Pembiayaan merupakan salah satu produk unggulan di Bank Syariah karena produk ini berbasis bagi hasil. Pembiayaan berbasis bagi hasil ini sangat diminati oleh nasabah karena kelebihannya. Baik bank syariah maupun nasabah secara bersama-sama menangung resiko usaha dan membagi hasil usaha berdasarkan metode bagi untung dan rugi (profit and loss sharing) atau bagi pendapatan (revenue sharing) antara kedua belah pihak berdasarkan nisbah yang disepakati sebelumnya. Pembiayaan dari bank secara langsung akan membantu masyarakat dalam penggunaan dana untuk kebutuhan pembiayaan yang ingin dilakukan.

Banyak bank berlomba-lomba untuk menarik perhatian dan kepercayaan mudharib (nasabah) untuk mengambil pembiayaan di bank tersebut. Pemberian kemudahan pembiayaan kepada mudharib harus sejalan dengan efektivitas peraturan yang telah diadakan oleh Bank Indonesia dalam hal pembiayaan. Pihak bank harus menjalankan ketentuan sesuai dengan Undang-undang yang terdapat pada hukum perbankan di Indonesia dan juga pengendalian internal (Internal Control) yang diharapkan dapat mengendalikan NPF (Non Performing Financing / pembiayaan bermasalah) sehingga diharapkan pelaksanaannya dapat menjadi lebih efektif.

Statistik Perbankan Syariah yang dikeluarkan Otoritas Jasa Keuangan (OJK) menyebutkan rasio pembiayaan bermasalah (Non Performing Financing/NPF) industri bank umum syariah per Juni 2016 mencapai 5,68\% (gross). Angka ini melampaui ketentuan, yakni maksimal 5\%. Sementara, NPF unit usaha syariah terkendali di level 3,49\% (gross). Secara keseluruhan, NPF perbankan syariah, baik bank umum syariah maupun unit usaha syariah, mencapai lebih dari 5\% per Juni 2016. Kenaikan rasio pembiayaan macet ini menjadi lampu kuning bagi industri perbankan syariah untuk lebih hati-hati dalam menyalurkan pembiayaan.

Dalam pemberian pembiayaan modal kerja diperlukan pengendalian internal yang berfungsi untuk mengurangi adanya kemungkinan ancaman-ancaman atau risiko-risiko 
yang dapat mengganggu kegiatan operasional perusahaan atau bahkan eksistensi kelangsungan hidup perusahaan.

Oleh karena itu, pihak pelaksana pembiayaan harus memiliki pemahaman yang kuat mengenai pembiayaan dan risiko-risiko yang mungkin terjadi apabila terjadi NPF serta harus dilakukan monitoring secara berkala, hati-hati dan ketat tanpa mengabaikan target pelepasan pembiayaan yang harus dicapai sesuai dengan kebijakan pemberian pembiayaan yang telah ditetapkan bank, dalam hal ini Bank Sulselbar Cabang Syariah Makassar memiliki Grup Kepatuhan yang memiliki salah satu desk job untuk memfilter pembiayaan (kredit) dan menganalisa kelayakan keuangan mudharib sebelum diberikan kepada pihak berwenang (Direksi dan Dewan Komisaris). Sedangkan kepatuhan Bank Sulselbar Cabang Syariah Makassar memiliki peranan dalam pemeriksaan pemenuhan peraturan pembiayaan yang berasal dari eksternal perusahaan (Bank Indonesia) yang terkait dengan pemberian pembiayaan kepada mudharib.

Mengingat pentingnya audit kepatuhan dalam dunia perbankan, dimana bank harus memahami aturan, kode etik dari Bank Indonesia yang memiliki acuan dasar untuk metode pengawasan dan penetapan tanggung jawab yang harus diterapkan di internal bank tersebut. Kasus yang pernah terjadi di perbankan Indonesia pada September 2012 lalu, salah satu kasus yang terjadi terdapat di salah satu Bank Syariah yang ada di Bogor tentang adanya fraud yang melibatkan auditee yang melakukan tindakan yang kurang terpuji dalam proses pembiayaan dimana adanya suatu pemberian yang diberikan mudharib kepada auditee agar pihak bank dapat memberikan pembiayaan. Salah satu kasus ini menjadi pembelajaran pada dunia perbankan di Indonesia, maka dapat disimpulkan bahwa audit kepatuhan tidak boleh dianggap remeh. Disamping itu, pemenuhan SDM bank yang cukup, anti fraud dan audit yang independen menjadi salah satu tolok ukur keberhasilan bank dalam mencapai kepatuhan dan pelayanan yang baik bagi nasabahnya.

Penelitian ini merupakan replikasi dari penelitian yang dilakukan oleh Irot, dkk (2013) meneliti tentang Pelaksanaan Audit Kepatuhan dalam Proses Pemberian Kredit pada PT. Bank Negara Indonesia (Persero) Tbk Kantor Wilayah Manado, Sentra Kredit Menengah Manado. Hasil penelitian Audit kepatuhan telah dilaksanakan dengan baik pada PT. Bank Negara Indonesia (Persero) Tbk, Sentra Kredit Menengah Manado, dimana dengan adanya audit kepatuhan dapat mengurangi risiko kredit hal ini dapat dilihat dari nilai kualitas kredit yang diberikan selama 2,5 tahun terakhir. Kolektibiliti per bulan Juni 2013 sebesar 95.19\% jauh lebih baik jika dibandingkan dengan kolektibiliti tahun 2011 sebesar 91.21\%. Kredit Non Performing Loan juga terus membaik, pada tahun 2011 sebesar Rp. 70.000. juta dan per Juni 2013 turun menjadi 40.000 juta.

\section{TINJAUAN PUSTAKA}

\subsection{Auditing}

Auditing merupakan suatu ilmu yang digunakan untuk melakukan penilaian terhadap pengendalian intern bertujuan untuk memberikan perlindungan dan pengamanan supaya dapat mendeteksi terjadinya penyelewengan dan ketidakwajaran yang dilakukan dalam perusahaan. 
Menurut Messier dkk (2014), auditing adalah suatu proses sistematis mendapatkan dan mengevaluasi buktibukti secara objektif sehubungan dengan asersi atas tindakan dan peristiwa ekonomi untuk memastikan tingkat kesesuaiaan antara asersi-asersi tersebut dan menetapkan kriteria serta mengkomunikasikan kepada pihak-pihak yang berkepentingan.

"Auditing is the accumulation and evaluation of evidence about information to determine and report on the degree of correspondence between the information and established criteria. Auditing should be done by a competent independent person" (Elder dan Beasley, 2011).

Auditing adalah pengumpulan dan evaluasi bukti tentang informasi untuk menentukan dan melaporkan derajat kesesuaian antara informasi itu dan kriteria yang telah diterapkan. Auditing harus dilakukan oleh orang yang kompeten dan independen.

Berdasarkan beberapa pengertian di atas, dapat dikatakan bahwa auditing merupakan suatu proses pemeriksaan yang dilakukan seseorang yang independen dan kompeten terhadap laporan keuangan, pengawasan intern, dan catatan akuntansi suatu perusahaan yang bertujuan mengevaluasi dan menilai secara objektif berdasarkan bukti-bukti yang diperoleh atas kinerja manajemen, dan menyampaikan hasilhasilnya kepada pemakai yang berkepentingan.

\subsection{Jenis Risiko}

Berdasarkan Peraturan Bank Indonesia nomor 5/8/PBI/2003 dan perubahannya PBI nomor 11/25/PBI/2009 tentang Penerapan
Manajemen Risiko bagi Bank Umum, terdapat 8 jenis risiko yang harus dikelola bank, yaitu sebagai berikut:

1. Risiko Kredit adalah Risiko akibat kegagalan debitur dan/atau pihak lain dalam memenuhi kewajiban kepada Bank.

2. Risiko Pasar adalah Risiko pada posisi neraca dan rekening administratif termasuk transaksi derivatif, akibat perubahan secara keseluruhan dari kondisi pasar, termasuk Risiko perubahan harga option.

3. Risiko Likuiditas adalah Risiko akibat ketidakmampuan Bank untuk memenuhi kewajiban yang jatuh tempo dari sumber pendanaan arus kas dan/atau dari aset likuid berkualitas tinggi yang dapat diagunkan, tanpa mengganggu aktivitas dan kondisi keuangan Bank.

4. Risiko Operasional adalah Risiko akibat ketidakcukupan dan/atau tidak berfungsinya proses internal, kesalahan manusia, kegagalan sistem, dan/atau adanya kejadian-kejadian eksternal yang mempengaruhi operasional Bank.

5. Risiko Hukum adalah Risiko akibat tuntutan hukum dan/atau kelemahan aspek yuridis.

6. Risiko Reputasi adalah Risiko akibat menurunnya tingkat kepercayaan stakeholder yang bersumber dari persepsi negatif terhadap Bank.

7. Risiko Stratejik adalah Risiko akibat ketidaktepatan dalam pengambilan dan/atau pelaksanaan suatu keputusan stratejik serta kegagalan dalam mengantisipasi perubahan lingkungan bisnis.

8. Risiko Kepatuhan adalah Risiko akibat Bank tidak mematuhi dan/atau tidak melaksanakan peraturan perundang- 
undangan dan ketentuan yang berlaku.

\subsection{Bank}

Menurut Undang-Undang Nomor 10 Tahun 1998, bank adalah badan usaha yang menghimpun dana dari masyarakat dalam bentuk simpanan dan menyalurkannya kepada masyarakat dalam bentuk kredit dan atau bentukbentuk lainnya dalam rangka meningkatkan taraf hidup rakyat banyak.

Sedangkan menurut Kasmir (2011), bank adalah lembaga keuangan yang kegiatan utamanya adalah menghimpun dana dari masyarakat dan menyalurkannya kembali dana tersebut kepada masyarakat serta memberikan jasa-jasa bank lainnya.

Pengertian di atas menjelaskan bahwa kegiatan utama bank adalah menghimpun dan menyalurkan dana. Bank merupakan salah satu pilihan yang terbaik untuk menghimpun dana dari masyarakat dalam bentuk simpanan.

Berdasarkan undang-undang RI No.7 tahun 1992 tentang perbankan sebagaimana telah diubah dengan undang-undang RI No.10 tahun 1998 tentang perbankan, maka bank dapat dibedakan menjadi:

1. Bank Umum adalah bank yang melaksanakan kegiatan usaha secara konvensional dan atau berdasarkan prinsip syariah yang dalam kegiatannya memberikan jasa dalam lalu lintas pembayaran.

2. Bank Perkreditan Rakyat (BPR) adalah Bank yang melaksanakan kegiatan usaha secara konvensional atau berdasarkan prinsip syariah, yang dalam kegiatannya tidak memberikan jasa dalam lalu lintas pembayaran.
3. Bank Syariah menurut UndangUndang Republik Indonesia Nomor 21 tahun 2008 tentang Perbankan Syariah, bank syariah adalah bank yang menjalankan kegiatan usahanya berdasarkan Prinsip Syariah dan menurut jenisnya terdiri atas Bank Umum Syariah (BUS) dan Bank Pembiayaan Rakyat Syariah (BPRS).

Menurut Heri Sudarsono (2015), bank syariah adalah lembaga keuangan negara yang memberikan kredit dan jasa-jasa lainnya di dalam lalu lintas pembayaran dan juga peredaran uang yang beroperasi dengan menggunakan prinsipprinsip syariah atau Islam.

Menurut Perwaatmadja (2007), bank syariah adalah bank yang beroperasi berdasarkan prinsip-prinsip syariah (Islam) dan tata caranya didasarkan pada ketentuan Al-Qur'an dan Al-Hadits. Pendapat ini sama dengan yang dikemukan oleh Muhammad Syafi'i Antonio (2012).

Istilah lain yang digunakan untuk sebutan Bank Syariah adalah Bank Islam. Secara akademik, istilah Islam dan Syariah memang mempunyai pengertian yang berbeda. Namun secara teknis untuk penyebutan Bank Islam dan Bank Syariah mempunyai pengertian yang sama.

\section{METODE PENELITIAN}

Penelitian ini menggunakan metode deskriptif kualitatif yaitu analisis data yang digunakan dengan cara memberikan penjelasan dengan memberikan predikat kepada variabel yang diteliti sesuai dengan kondisi yang sebenarnya. Adapun tujuan dari penelitian ini adalah untuk mengungkapkan kejadian atau fakta, 
keadaan, fenomena, variabel dan keadaan yang terjadi saat penelitian berlangsung dengan menyuguhkan apa yang sebenarnya terjadi. Dalam hal ini peneliti menggunakan pendekatan audit berbasis risiko, yaitu pendekatan audit dimana dilakukan pengecekan terhadap keselarasan antara kebijakan dan prosedur yang dilakukan dengan ketetapan regulasi. Jadi, Bank Sulselbar Cabang Syariah Makassar harus sejalan dengan peraturan atau prosedur yang telah diadakan oleh Bank Indonesia (BI) dalam hal pembiayaan.

\section{HASIL DAN PEMBAHASAN}

Pembiayaan Modal Kerja Bank Sulselbar Cabang Syariah adalah fasilitas pembiayaan konsumtif dengan pola syariah yang diberikan kepada perorangan untuk memenuhi kebutuhan modal kerjanya yang disesuaikan dengan kebutuhan pembiayaan dan kemampuan msing-masing pemohon.

1. Fitur pembiayaan modal kerja:

a. Berdasarkan prinsip syariah.

b. Penggunaannya untuk membantu nasabah mengelola usahanya.

c. Nasabah mempunyai usaha serta sumber pembayaran yang jelas.

2. Manfaat pembiayaan modal kerja:
a. Proses pembiayaan mudah dan cepat.
b. Jangka waktu pembiayaan maksimal 5 tahun.

c. Pembiayaan Nasabah dapat dicover oleh Perusahaan Penjaminan.

\subsection{Posedur Pemberian Pembiayaan Modal Kerja}

Sama dengan yang banyak dilakukan bank lainnya sistem atau prosedur pemberian pembiayaan pada Bank Sulselbar Cabang Syariah Makassar tidak jauh berbeda, yaitu dimana proses dimulai ketika nasabah yang mau mengajukan pembiayaan datang ke bank dengan membawa semua persyaratan yang diminta, kemudian baru dianalisis apakah pembiayaan layak diberikan atau tidak.

1. Bagian yang terkait

Bagian-bagian yang terkait dalam sistem pemberian pembiayaan pada Bank Sulsebar Cabang Syariah Makassar adalah sebagai berikut:

a. Bagian atau Seksi Pemasaran

b. Bagian atau Seksi Operasional

c. Pimpinan Cabang sebagai pejabat pemutus.

2. Prosedur dalam Pemberian Pembiayaan

Dalam memberikan Pembiayaan terhadap nasabah Bank Sulselbar Cabang Syariah Makassar memberikan dua alernatif kepada nasabah yaitu:

a. Nasabah datang ke Bank.

b. Bank datang ke Nasabah. 
Gambar 4.2 Flowchart Pemberian Pembiayaan Pada

Bank Sulselbar Cabang Syariah Makassar

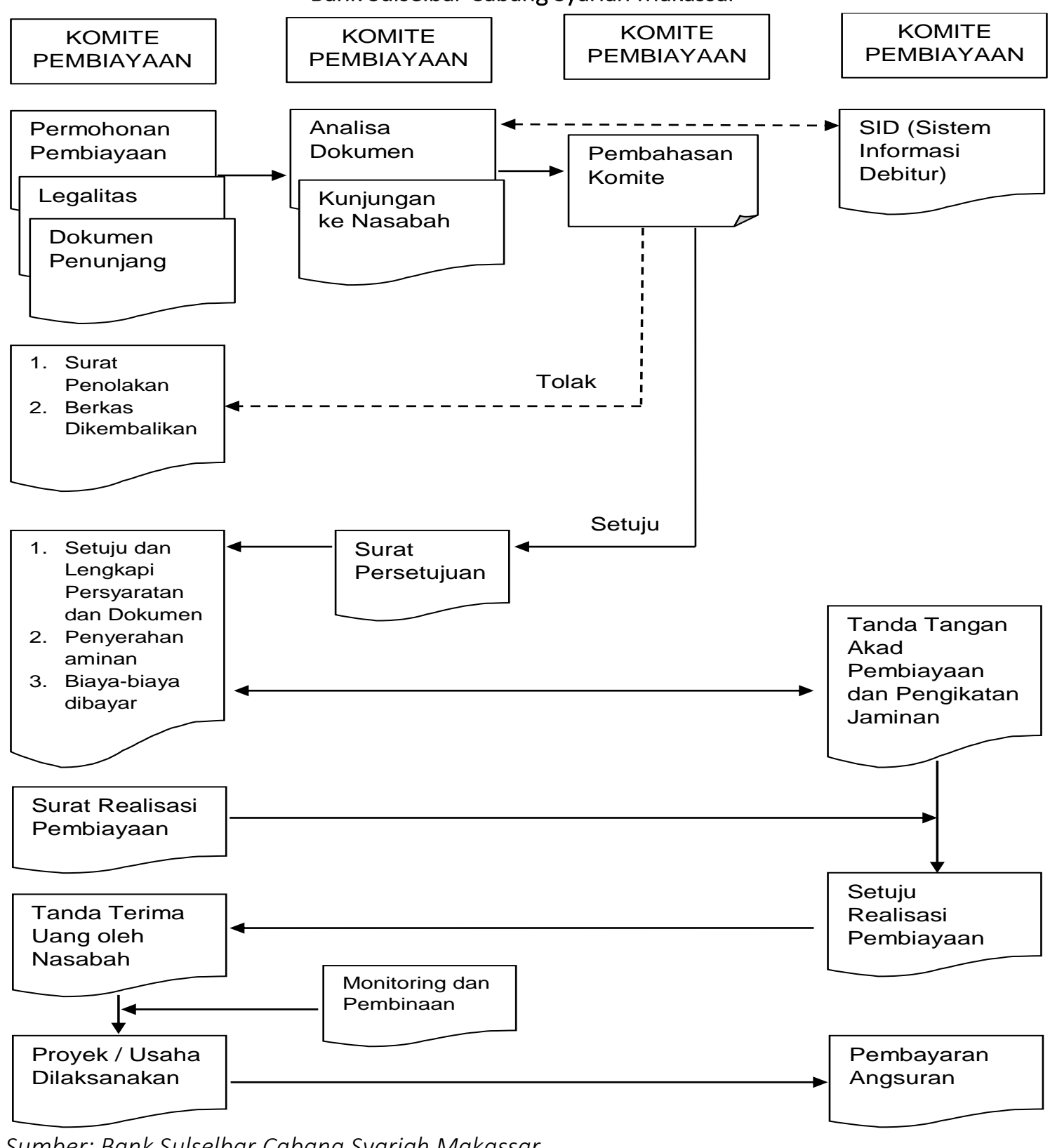

Prosedur pemberian pembiayaan yang ada pada Bank Sulselbar Cabang Syariah Makassar adalah sebagai berikut:

1. Calon nasabah datang ke bank atau didatangi dengan membawa surat permohonan pembiayaan dengan dilengkapi dokumen, laporan keuangan, photo copy jaminanjaminan, dan persyaratan lainnya yang sudah ditentukan.
2. Selanjutnya akan diadakan analisa kepada nasabah yang meliputi langkah-langkah sebagai berikut :

a. Pengumpulan data: menyusun rencana (data yang diperlukan, sumber dan pendekatan).

b. Verfikasi data: kunjungan setempat ke lokasi proyek atau tempat usaha nasabah, mencari informasi bank ke BI/bank lain, mangecek ke 
pembeli, pemasok, pesaing (yang tergolong dominan).

c. Analisa laporan keuangan: analisa ratio keuangan, analisa rugi/laba dan neraca, analisa rekonsiliasi harta tetap dan pemodalan, analisa pernyataan pengadaan kas.

d. Analisa rating: analisa rating untuk menetapkan kategori risiko (analisa risiko umum dan khusus), analisa rating untuk menetapkan prioritas pemasaran.

e. Analisa aspek perusahaan: analisa aspek umum organisasi dan manajemen, analisa aspek teknis/produksi (lokasi, teknologi, kapasitas, bahan baku, tenaga kerja dan PLC), analisa aspek pemasaran (peluang pasar, harga, barang subtitusi, persaingan dan strategi).

f. Analisa proyeksi keuangan: menetapkan asumsi-asumsi proyek baru, menyusun proyeksi arus kas dan proyeksi keuangan lainnya, evaluasi proyek investasi, evaluasi kebutuhan fasilitas pembiayaan.

g. Evaluasi jaminan: meneliti dokumen-dokumen barang jaminan, jaminan tanah harus dicek ke BPN, kemungkinan pengikatannya, analisa CEV jaminan.

h. Penetapan struktur fasilitas pembiayaan dan jaminan: menyusun ikhtisar fasilitas pembiayaan (jenis dan maksimum), dan jaminannya (jenis dan pengikatannya, usulan fasilitas pembiayaan berikut penyertaannya.

3. Setelah melakukan analisa tesebut petugas akan mempertimbangkan hasil analisa apakah layak atau tidak pembiayaan diberikan. Apabila tidak, maka calon nasabah harus kembali lagi dari awal dalam melakukan permohonan pembiayaan, dan apabila layak maka hasil dari analisa akan diproses oleh petugas.

4. Hasil dari proses analisa ini akan diserahkan kepada Komite Pembiayaan untuk dilakukan Pembahasan Komite. Dalam hal ini Komite Pembiayaan bisa saja melakukan penolakan terhadap permohonan pembiayaan nasabah. Apabila ini terjadi maka permohonan dikembalikan ke Nasabah, disertai dengan diberikannya Surat Penolakan dan berkas-berkas dikembalikan. Bila Komite Pembiayaan setuju maka permohonan ini diteruskan kepada bagian administrasi untuk direalisasikan. Hal ini dibuktikan dengan adanya diterbitkan Surat Persetujuan.

5. Setelah menerima Surat Persetujuan, Nasabah selanjutnya melengkapi persyaratan dan Dokumen, menyerahkan jaminan, dan membayar biaya-biaya administrasi.

6. Tanda tangan akad pembiayaan, mengenai bagi hasil antara pihak Bank dan Nasabah.

7. Pengikatan jaminan, pengikatan dilakukan penandatanganan akad yang dilakukan antara bank syariah dan nasabah dan penandatanganan akad yang disaksikan oleh notaris. Setelah itu diterbitkan Surat Realisasi Pembiayaan. Kemudian uang diterima oleh Nasabah.

8. Setelah semua tahapan dilakukan dan dipenuhi maka proses yang terakhir dari pembiayaan adalah proses monitoring dan pembinaan. 


\subsection{Manajemen Risiko Pembiayaan}

Dengan tetap mengacu kepada Risk Management Framework, Manajemen Risiko Pembiayaan Perseroan secara singkat diuraikan sebagai berikut:

1. Penerapan Risk Based Audit untuk pengujian model manajemen risiko Pembiayaan oleh Audit Intern yang secara continue dievaluasi oleh Komite Audit di level Dewan Komisaris.

2. Penyusunan atau penyempurnaan Kebijakan dan SOP perkreditan atau pembiayaan yang terdokumentasi dengan baik yang disosialisasikan kepada seluruh unit kerja (termasuk penetapan rasio agunan dan penetapan standar proses identifikasi, pengukuran, pemantauan dan pengendalian risiko pembiayaan.

3. Penetapan Financing Risk Tolerance berdasarkan risk appetite yang dituangkan dalam Rencana bisnis bank yang dievaluasi secara periodik, antara lain penetapan:

a. Target Non Performing Financing (NPF) di atas standar Bank Indonesia.

b. Target per segment pembiayaan.

c. Target Financing Recovery.

4. Penetapan struktur organisasi mengacu kepada Four Eyes Principles yang secara jelas memisahkan antara fungsi pemutus, monitoring risiko pembiayaan serta kejelasan tanggungjawab masing masing unit/pegawai.

5. Penetapan standar kualifikasi bagi pegawai yang terlibat dalam keputusan kredit/pembiayaan dan monitoring pembiayaan.

6. Penggunaan Teknologi Informasi yang memudahkan proses reporting guna monitoring risiko pembiayaan dan Early Warning System.
7. Penerapan Risk Based Audit untuk pengujian model manajemen risiko pembiayaan oleh Audit Intern yang secara continue dievaluasi oleh Komite Audit di level Dewan Komisaris.

8. Rekomendasi penyempurnaan model Manajemen Risiko pembiayaan oleh Komite Manajemen Risiko yang secara continue dipantau oleh Komite Pemantau Risiko di level Dewan Komisaris.

\subsection{Tujuan Audit Kepatuhan atas Pemberian Pembiayaan Modal Kerja}

Berorientasi terhadap peningkatan efisiensi dan efektivitas pemberian pembiayaan modal kerja, maka harus diketahui tujuan audit kepatuhan atas pemberian pembiayaan modal kerja, yaitu antara lain:

1. Menilai audit kepatuhan atas pemberian pembiayaan modal kerja dan untuk memastikan apakah prosedur pemberian pembiayaan modal kerja dan administrasi pembiayaan sudah dilaksanakan dengan baik dan benar.

2. Menilai ketaatan terhadap prosedur pembiayaan modal kerja dalam pelaksanaan prosedur yang telah ditetapkan.

3. Mendeteksi adanya kelemahan dalam kegiatan pemberian pembiayaan modal kerja.

\subsection{Kajian Kepatuhan atas Pemberian Pembiayaan Modal Kerja}

Bank Sulselbar dalam hal peraturan dan kebijakan secara eksternal berpedoman pada Bank Indonesia (BI) dan Otoritas Jasa Keuangan (OJK). Serta peraturan dan kebijakan secara internal berpedoman pada yang dibuat oleh Bank 
Sulselbar sendiri seperti Standar Operasional Prosedur (SOP) dan Buku Pedoman Perusahaan (BPP).

Dalam melaksanakan pemeriksaan, auditor menggunakan perangkat pemeriksaan yang disebut dengan kajian kepatuhan. Kajian kepatuhan pemberian pembiayaan modal kerja dibuat untuk setiap transaksi atau aktivitas pembiayaan yang ada ada bank meliputi kajian kepatuhan atas pemberian pembiayaan modal kerja oleh bank dan kajian kepatuhan atas penggunaan dana pembiayaan oleh Debitur.

Kajian kepatuhan atas prosedur pemberian pembiayaan modal kerja untuk pihak bank dimaksudkan untuk mengetahui apakah terdapat kelemahan dalam proses pemberian pembiayaan mulai dari permohonan pengajuan pembiayaan oleh Debitur sampai permohonan atas pengajuan pembiayaan tersebut disetujui oleh pihak bank yang memberikan pembiayaan. Sedangkan kajian kepatuhan atas penggunaan dana pembiayaan yang dilakukan oleh Debitur dimaksudkan untuk mengetahui apakah bank selalu memeriksa kondisi dari Debiturnya serta memantau aktivitas penggunaan dana pembiayaan yang dilakukan oleh Debitur.

\subsection{Pelaksanaan Audit Kepatuhan Terhadap Pemberian Pembiayaan Modal Kerja}

Dalam pelaksanaan audit kepatuhan atas prosedur pemberian pembiayaan modal kerja pada Bank Sulselbar Cabang Syariah Makassar, penulis menggunakan questioner (daftar pertanyaan), dan jawaban yang diberikan berupa ya dan tidak.

Tabel 4.1 Daftar Internal Control Questionaire (ICQ) Audit Kepatuhan

Atas prosedur pemberian pembiayaan modal kerja

\begin{tabular}{|c|c|c|c|}
\hline No. & Pertanyaan & Ya & Tidak \\
\hline 1 & $\begin{array}{l}\text { Apakah Bank Sulselbar Cabang Syariah Makassar telah memiliki pedoman } \\
\text { di bidang pembiayaan? }\end{array}$ & $\checkmark$ & \\
\hline 2 & $\begin{array}{l}\text { Apakah bagian pembiayaan memiliki pengetahuan atau kecakapan yang } \\
\text { sesuai dengan masing-masing tugas dan tanggung jawab? }\end{array}$ & $\checkmark$ & \\
\hline 3 & $\begin{array}{l}\text { Apakah terdapat pembagian wewenang untuk pemutusan pemberian } \\
\text { pembiayaan? }\end{array}$ & $\checkmark$ & \\
\hline 4 & $\begin{array}{l}\text { Dalam memberikan wewenang apakah Bank Sulselbar Cabang Syariah } \\
\text { Makassar secara aktif melakukan pengidentifikasian untuk memilih } \\
\text { nasabah-nasabah dapat dipercaya (bonafide)? }\end{array}$ & $\checkmark$ & \\
\hline 5 & $\begin{array}{l}\text { Apakah oleh Bank Sulselbar Cabang Syariah Makassar secara teratur atau } \\
\text { periodik diadakan penilaian kolektibilitas para debiturnya? }\end{array}$ & $\checkmark$ & \\
\hline 6 & $\begin{array}{l}\text { Apakah sistem pengarsipan dari bermacam-macam dokumen yang } \\
\text { menyangkut pembiayaan telah diarsipkan secara sistematis? }\end{array}$ & $\checkmark$ & \\
\hline 7 & $\begin{array}{l}\text { Apakah pemutusan pembiayaan didukung oleh analisa dan prosedur yang } \\
\text { biasa dilakukan? }\end{array}$ & $\checkmark$ & \\
\hline 8 & $\begin{array}{l}\text { Apakah pemberian pembiayaan sesuai dengan batas maksimum } \\
\text { pembiayaan yang diberikan? }\end{array}$ & $\checkmark$ & \\
\hline 9 & Apakah penggolongan (kolektibilitas) telah sesuai dengan ketentuan? & $\checkmark$ & \\
\hline 10 & Apakah dalam melakukan penilaian barang jaminan bekerja sama dengan & $\checkmark$ & \\
\hline
\end{tabular}




\begin{tabular}{|c|l|c|c|}
\hline 11 & $\begin{array}{l}\text { Apakah pembiayaan yang diberikan di-cover atau ditutup dengan jaminan } \\
\text { yang memadai? }\end{array}$ & $\checkmark$ & \\
\hline 12 & Apakah setiap jaminan kredit di-cover asuransinya? & $\checkmark$ & \\
\hline 13 & $\begin{array}{l}\text { Apakah semua pembiayaan yang diberikan selalu dibuatkan ikatan } \\
\text { perjanjian pembiayaan yang lengkap? }\end{array}$ & $\checkmark$ & \\
\hline 14 & $\begin{array}{l}\text { Apakah setiap perjanjian yang akan jatuh tempo telah diproses sehingga } \\
\text { tidak ditemui adanya over draft? }\end{array}$ & $\checkmark$ & \\
\hline 15 & $\begin{array}{l}\text { Apakah inspeksi on the spot ke tempat usaha para Debitur dilakukan } \\
\text { secara teratur dan terencana? }\end{array}$ & $\checkmark$ & \\
\hline 16 & $\begin{array}{l}\text { Apakah laporan keuangan dari para Debitur selalu diaudit oleh Akuntan } \\
\text { Publik? }\end{array}$ & $\checkmark$ & \\
\hline 17 & $\begin{array}{l}\text { Apakah Bank menerima laporan keuangan, posisi stock, dan laporan } \\
\text { kegiatan usahanya dari Debitur secara teratur minimal satu tahun sekali? }\end{array}$ & $\checkmark$ & \\
\hline
\end{tabular}

Dari hasil questioner tersebut di atas, penulis dapat menganalisa bahwa:

\section{Internal Control atas kegiatan} pembiayaan sudah cukup baik. Bank Sulselbar Cabang Syariah Makassar telah memiliki pedoman di bidang pembiayaan. Hal ini akan memudahkan bagian pembiayaan dalam melakukan kegiatannya. Penempatan bagian pembiayaan sesuai dengan kemampuannya dilakukan agar setiap pembiayaan yang ada dapat dianalisis dengan baik.

2. Sistem pengarsipan dokumen dilakukan secara sistematis sehinga memudahkan karyawan dalam mencari data-data mengenai Nasabah debitur yang ditanganinya.

3. Internal Control untuk proses pembiayaan yang ada pada Bank Sulselbar Cabang Syariah Makassar juga sudah baik. Setiap pembiayaan yang diberikan telah melalui prosedur yang ditetapkan dan analisis yang dilakukan mencakup pemeriksaan kelengkapan dokumen debitur serta peninjauan langsung ke tempat usaha debitur.
Bagi Bank Sulselbar, sangat penting diadakan pelaksanaan kepatuhan terhadap pembiayaan modal kerja yang berfungsi untuk mengurangi adanya kemungkinan ancaman-ancaman atau risiko-risiko yang dapat mengganggu kegiatan operasional perusahaan atau bahkan eksistensi kelangsungan hidup perusahaan. Karena itu, seluruh tahapan-tahapan atau prosedur pembiayaan harus dilaksanakan atau dipatuhi sebelum pengambilan keputusan pembiayaan dapat direalisasikan. Dan setiap tahapan tersebut tidak luput dari pengawasan Grup Kepatuhan agar setiap bagian atau seksi yang terkait pada tahapan tersebut bertanggung jawab secara profesional.

Tidak hanya itu, setelah pengajuan pembiayaan tersebut disetujui oleh pihak Bank Sulselbar, Bank selalu memeriksa kondisi dari Debiturnya, memantau aktivitas penggunaan dana pembiayaan yang dilakukan oleh Debitur, serta memberikan pembinaan. Apabila terjadi tidak tercapainya target, maka officer bank segera melakukan tindakan seperti turun langsung ke lapangan menemui Nasabah untuk mengetahui 
permasalahan yang dialami Nasabah, kemudian memberikan solusi penyelesaian masalah kepada Nasabah.

\section{PENUTUP}

\subsection{Simpulan}

Audit Kepatuhan yang dilaksanakan oleh Direktur Kepatuhan dan Satuan Kerja Kepatuhan telah berjalan dengan baik sesuai dengan tugas dan kewenangannya dan menjaga independensinya dengan baik karena memiliki pedoman kerja, sistem dan prosedur kerja yang telah mengacu kepada ketentuan perundangundangan yang berlaku.

Koordinasi antara DPS (Dewan Pengawas Syariah) dengan Grup Kepatuhan telah dijalankan secara rutin, minimal satu kali dalam sebulan dalam rapat rutin DPS (Dewan Pengawas Syariah).

PT. Bank Sulselbar Unit Usaha Syariah (UUS) memiliki 1 (satu) orang Direktur Kepatuhan yang bertugas memastikan kepatuhan terhadap ketentuan Bank Indonesia dan peraturan perundang-undangan lainnya, yang merupakan satu-kesatuan dengan PT. Bank Sulselbar.

Sampai saat ini fungsi kepatuhan masih bergabung dengan personil dari PT. Bank Sulselbar (Konvensional).

Dalam melaksanakan pemeriksaan, auditor menggunakan perangkat pemeriksaan yang disebut dengan kajian kepatuhan. Kajian kepatuhan pemberian pembiayaan modal kerja dibuat untuk setiap transaksi atau aktivitas pembiayaan yang ada ada bank meliputi kajian kepatuhan atas pemberian pembiayaan modal kerja oleh bank dan kajian kepatuhan atas penggunaan dana pembiayaan oleh Debitur.
Kemudian mengenai prosedur pemberian pembiayaan pada bank Sulselbar Cabang Syariah Makassar sudah sesuai dengan teori yang dikemukakan oleh Sunarto (2007), bahwa proses pembiayaan yang sehat yaitu pembiayaan yang berimplikasi pada investasi yang halal dan baik serta menghasilkan return sebagaimana yang diharapkan, atau bahkan lebih, berimplikasi pada kondisi bank yang sehat serta berimplikasi pada peningkatan kinerja sektor riil yang dibiayai. Hal ini dibuktikan dengan hasil penelitian yang dilakukan bahwa pemberian pembiayaan kepada nasabah telah sesuai dengan prosedur. Karena sebelum terjadi pencairan dana melalui proses panjang, ada beberapa tahapan yang harus dipenuhi nasabah serta bank sangat selektif dalam hal pemberian pembiayaan.

Maka dari itu Penulis mengambil kesimpulan bahwa Audit kepatuhan terhadap prosedur pemberian pembiayaan modal kerja pada Bank Sulselbar Cabang Syariah Makassar sudah sesuai dengan ketentuan Peraturan Bank Indonesia dan undangundang.

\section{REFERENSI}

Agoes, Sukrisno. 2012. Auditing Petunjuk Praktis Pemeriksaan Akuntan Oleh Akuntan Publik. Edisi 4. Jilid 1. Jakarta: Salemba Empat.

Antonio, Muhammad Syafi'i. 2012. Bank Syariah dari Teori ke Praktik. Depok: Gema Insani.

Basir, Muhammad. 2007. Analisis Sistem Dan Prosedur Pemberian Kredit Modal Kerja Pada Pt Bank Rakyat Indonesia (Persero) Tbk Cabang Makale. STIE-YPUP Makassar. 
Cahyadi, Lukieto. 2014. Analisis Prosedur Pemberian Kredit pada PT. BPR Nusantara Bona Pasogit 18 Cabang Tebing Tinggi. Jurnal Ilmiah Accounting Changes. Volume 2, Nomor 2, 31-39, Oktober 2014.

Elder, Randal J, dkk. 2011. Jasa Audit dan Assurance. Buku 1. Jakarta: Salemba Empat.

Irot, Ronald David A, dkk. 2013. Pelaksanaan Audit Kepatuhan Dalam Proses Pemberian Kredit di PT. Bank Negara Indonesia (Persero) TBK, Sentra Kredit Menengah Manado. Jurnal Riset Akuntansi dan Auditing Magister Akuntansi Fakultas Ekonomi Universitas Sam Ratulangi. Volume 4 - Nomor 2, 74-98, Desember 2013.

Ismail. 2011. Perbankan Syariah. Jakarta: Kencana.

Junaidi dan Cherrya. 2012. Audit Ketaatan Prosedur Pengelolaan Piutang dalam Meminimalisir Piutang Tak Tertagih pada PT Calmic Indonesia Cabang Palembang. Prodi Akuntansi STIE MDP.

Kasmir. 2011. Dasar-Dasar Perbankan. Jakarta: PT. Raja Grafindo Persada.

Kasmir. 2011. Manajemen Perbankan. Jakarta: Rajawali Pers.

Lewis, Mervyn K., dan Latifa M. Algaoud. 2007. Perbankan Syariah: PrinsipPrinsip, dan Prospek. Jakarta: PT. Serambi Ilmu Semesta.

Messier, William F, dkk. 2014. Jasa Audit dan Assurance (Pendekatan Sistematis). Edisi 8. Buku 1. Jakarta: Salemba Empat.

Mulazid, Ade Sofyan. 2016. Pelaksanaan Sharia Compliance pada Bank Syariah Studi Kasus pada Bank Syariah Mandiri Jakarta. Fakultas Ekonomi dan Binis UIN Syarif
Hidayatullah. Madania Volume 20, Nomor 1, Juni 2016.

Mulyadi. 2011. Auditing. Edisi 6. Jakarta: Salemba Empat.

Mulyaningrum, Martha Dwi. 2016. Analisis Manajemen Risiko Perbankan dalam Meminimalisir Kredit Bermasalah di Bidang Kredit Modal Kerja pada PT Bank Rakyat Indonesia (Persero) Tbk. Cabang Jombang. Jurnal Administrasi Bisnis Universitas Brawijaya. Volume 32, Nomor 1, Maret 2016.

Perwaatmadja, Karnaen A., dan Hendri Tanjung. 2007. Bank Syariah. Jakarta: Celestial Publishing.

Pratolo, Suryo. 2015. Audit Kinerja Manajemen: Konsep dan Aplikasinya. Yogyakarta: LP3M (Lembaga Penelitian, Publikasi dan Pengabdian Masyarakat) Universitas Muhammadiyah Yogyakarta.

Putri, Guruh Tika Ferayanti. 2010. Tinjauan atas Prosedur Pemberian Kredit pada Primkopad Pusdik Passus. Jurnal Prodi Akuntansi Fakultas Ekonomi Universitas Komputer Indonesia Bandung.

Qodar, Lailani. 2016. Pembiayaan Bermasalah (Non Performing Financing) PT. Bank Syariah Mandiri. Skripsi. Jakarta: UIN Syarif Hidayatullah Jakarta.

Rivai, Veithzal, dan Arviyan Arifin. 2010. Islamic Banking: Sebuah Teori, Konsep dan Aplikasi. Jakarta: PT. Bumi Aksara.

Rivai, Veithzal. 2007. Islamic Financial Management. Jakarta: PT. Rajawali Press.

Rosy, Shella Nevalina. 2014. Analisis Internal Control Dalam Prosedur Pemberian Kredit Terhadap Usaha Mikro pada Kospin Dua Dara. Universitas Dian Nuswantoro Semarang. 
Sudarsono, Heri. 2015. Bank dan Lembaga Keuangan Syariah. Edisi 4. Yogyakarta: Ekonisia.

Sulhan, M., dan Ely Siswanto. 2008. Manajemen Bank: Konvensional dan Syariah. Malang: UIN Malang Press.

Wangsawidjaja. 2012. Pembiayaan Bank Syariah. Jakarta: PT Gramedia Pustaka.

Zakiyani, Irkhalia. 2015. Analisis Kelayakan Nasabah Pembiayaan Modal Kerja (Study Kasus di KJKS Binama Semarang). Skripsi. Semarang: UIN Walisongo Semarang.

Zulkifli, Sunarto. 2007. Panduan Praktis Transaksi Perbankan Syariah. Jakarta: Zikrul Hakim. 